\title{
LANDSCAPE AS AN APPROACH FOR DEVELOPMENT AROUND RIVERS
}

\author{
Dalia Wagih A. ElHalim \\ Associate Professor, Architectural Department- Faculty of Engineering at Mataria - Helwan University \\ Dalia_Said@m-eng.helwan.edu.eg \\ daliawagih_arch@yahoo.com
}

\begin{abstract}
Urban development sometimes has negative impact on rivers. Landscape as one of the fields of development can be a gate to save rivers by regarding its needs. By pinpointing landscape around rivers, the paper aims to find out the main features that can be considered as a guide in urban development concerning rivers through both theoretical and analytical studies. In the theoretical study the paper discusses some questions such as: What are the contents of nature and their needs? What are the needs of rivers that have to be respected during urban development? What is the relationship between rivers and landscape? The study concludes an outline for landscape design to be a guide in developing urban with respect to rivers. Then the paper examines in the analytical study a guide outline resulted from the theoretical study, to measure the success or failure of urban development using a selection of rivers as samples.
\end{abstract}

\section{KEYWORDS}

Landscape; Planning; Urban Development; Urban Rivers; Nature. 


\section{INTRODUCTION}

River banks are interesting areas for establishing cities because people prefer to be close to the most important source for life which is water. Due to the establishment of cities, many civilizations are settled along them such as the Egyptian civilization around the River Nile [1]. Landscape as one of the most important aspects in showing the identities of cities, and as one of the main tools in cities to comprise the natural beauty of any region, it can be a successful approach for developing cities [2].

\section{METHODOLOGY}

The research hypothesis is concerned with the idea of reserving rivers by the wise usage of landscape, as a main tool in urban development. The research aims to find out the main features of landscape that have to be regarded in urban development around rivers. Therefore, the research concluded a list of these features that are applied on selected rivers to measure the success or failure of urban development around these rivers.

\section{NATURE AND THE NEEDS OF RIVERS}

Nature with its components air, water, greens, etc. need natural balance, and it has the right to exist freely. Rivers as one of the components of nature, need consideration to provide many requirements for life such as freshwater, and aesthetic values. Rivers are influenced by four main natural features that can be summarized in: river typology, which is responsible for the natural dynamic system of the river, it can be classified into geology, geomorphology, and climate, river morphology that reflects a balance of processes which operate through, and upon the river, biological components that can be summarized in the biological features, the degree of naturalism, variety of species, and vegetation, natural hazards that are mostly associated with floods, and soil erosion processes [3]. Rivers need to be restored by preserving their natural features, and eliminating the negative impacts of human activities.

\section{THE IMPORTANCE OF RIVERS}

Rivers are important naturally, functionally, and aesthetically. In nature, rivers have many roles in helping to discharge floods, providing important habitats for animals and plants, providing ecological benefits such as water supply, pollution control and biological protection. Functionally, rivers have remarkable benefits on economy such as tourism, increase the value of land, irrigation, usage in many types of industries, and transportation. Moreover, there are many social benefits such as providing pure water for drinking, opportunities for sports such as fishing, 
boating, and swimming. Aesthetically, rivers provide marvelous scenes, amusement passages on their banks for enjoyment and relaxation [5] [6].

\section{NEGATIVE IMPACTS ON RIVERS}

In spite of the importance of rivers, they face many negative impacts that threaten their existence. Some of these impacts can be summarized in urbanization, and human activities. Urban areas are rapidly expanding causing the degradation of many rivers, and threatening their biodiversity [8]. Towers, and dense buildings along the banks do not only prevent the flow of natural air, but also threaten the recovery of natural ecological environment. Lands across rivers that are used for various commercial purposes affect rivers and their banks because they lead to the reduction of the cross section of the river, by adding difficulty to flood control that severely affects its passage [9]. Hard surfaces that are used around rivers, such as roads, prevent the natural drainage of water through soil that results in increasing floods erosion, pollution, and decreased habitat. To solve this problem, the natural flow of water has to be restored by minimizing the usage of hard surfaces around rivers. This can be achieved by using green roofs, and sustainable system for urban drainage with managing groundwater to reduce the rate and volume of run-off [11]. Human activities have a significant impact on rivers. For example, pollution increases due to different activities, and with the absence or lack of wise management for this dangerous impact. Pollution can be resulted from many sources, the main of which are farm fields, lawns, roads, parking lots, storms, and flooding [12]. Hydroelectric dams are considered the most dangerous human activity because dams can affect landscape-level patterns of aquatic biodiversity by preventing the passage of aquatic fauna that are economically important for fish's food [13].

\section{THE RELATIONSHIP BETWEEN RIVERS AND LANDSCAPE}

In recent years, most cities have begun to pay attention to the landscape design around rivers, and tried not only to protect the ecological environment but also provide a place for recreation [6]. Urban landscape is an important tool to fulfill people's needs in entertainment and emotions, it affects humans' psychologically by keeping them away from their daily life stress [2]. Rivers are shaped by their landscapes as much as landscapes are shaped by rivers [13]. Both has positive and negative impacts on each other that must be regarded.

\subsection{The Impact of Landscape on Rivers}

Landscape has positive impacts on rivers as green areas not only form an ecological green corridor that benefit both habitats and people, but also act as a filter system 
for the sewage flowing from the road on riversides [10]. Green areas can cool rivers, prevent the erosion of soil on the riversides, offer shade to people, and animals. Moreover, using hard natural elements such as gravel can provide important linkages for wildlife [11]. Increasing riparian vegetation increases biodiversity, decreases the amount of polluted surface runoff, increases the aesthetic value, and provides habitats for wildlife [8]. Buffer zones protect the ecological integrity of rivers, enhance connections between wildlife habitats, and allow rivers to function more naturally. Plants provide shelter and food for different habitats, act as visual buffers, greenbelts, and recreation areas for people [7].

Landscape has negative impacts on rivers as hardscapes such as roads and sidewalks that prevent the water from rains to penetrate the soil, so it decreases the groundwater which is essential for greens. They act as obstacles in front of the storm water that lead to over flow, and floods that result in increasing the volume and the velocity of rainwater runoff. Moreover, they increase the pollution to rivers that is resulted from fertilizers, heavy metals, and bacteria which take place in paved roads [1].

\subsection{The Impact of Rivers on Landscape}

Rivers affect landscape around them, as its existence is considered a main constraint for landscapers, through which they can create many excited, comfortable, and attractive areas. The designer exploits the positive impacts of rivers in landscaping as establishing areas for relaxation in front of rivers to provide psychological effects, finding excited places by observing the movement of water and its vibration, matching places as good scenes by the reflection of the surroundings with its beauty on the surface of the river [14], providing comfortable zones by cooling weather, controlling noise, and decreasing pollution, fulfilling recreational functions, and providing different opportunities for connection with the natural context [7], in addition to providing fresh water for irrigating green areas.

\section{PROPOSED OUTLINE}

To develop and restore rivers through the design of landscape, there are different roles of many partners that have to be considered. These roles can be summarized in: public, government, and planners' responsibilities.

\subsection{The Role of Public}

Different people from society should be involved in taking decision to develop cities around rivers [1]. This involvement with experts can help to establish conclusions, and comparisons about profiles of aesthetical characteristics of urban watercourses, help in defining priorities in urban rehabilitation processes and 
policies, take into account landscape aesthetic values, which try to include expert procedures, different inputs from public surveys, and human values assessment [3]. Partnerships are the key to bring stakeholders with different resources, and skills to solve multi-faceted problems. NGOs/NPOs essentially initiate activities, create groups among communities to campaign for a healthy river [12], share, and collect funding, and donations from many different sources such as: local governments, local land owners and general public [8].

\subsection{The Role of Government}

Governments have to restore the river itself by reconstruction, and rehabilitation. In order to achieve this, governments have to optimize the patterns of economic development, establish restricted regulation to exploit and utilize intensity, manage water resources, and other river elements. In other words, negative impacts of cities should be ended by the control of governments through regulations. Problems should be solved to restore rivers from the ecological approach to reinforce their existence that have positive impacts on different fields such as economic and social ones. This can be achieved by the wise awareness of governments to establish, and manage development around rivers [4].

\subsection{The Role of Planners}

Planners have to contact governments to find out the problems, plan, design, and put the strategies for landscape around rivers to fulfill the requirements of both rivers, and cities with scientific approaches. In order to have successful work, planners have to consider the opinion of public before any decision [2]. They have to educate the public on the direct, and indirect benefits of enhancing local rivers that create good relationships between public and rivers, which in turn increase the chance of successful projects [8]. By increasing the awareness of public, they will take action to improve the condition of rivers. This can be achieved by establishing education campaign, which can take place by the cooperation between experts and NEGOs, for both the impact of people attitudes towards rivers, and the importance of rivers to people [12]. Planners have to restore rivers by building, among others shallow river banks [5]. The grey section of urban rivers (the section that lies between water and land) is an important chain in nature's ecological system. Therefore, planners should consider the human oriented designing principle in the landscape planning, especially the planning of grey section. Planners have to keep the line shape of rivers and to give back space to rivers, also to construct ecological corridor with sustainable development. The urban river landscape should be designed in order to realize the visual pleasure as well as the ecological sustainability [10]. Some important aspects such as regional development patterns, natural and cultural history, flood control, public access, recreation, and education 
should be taken into consideration. Moreover, it is important to understand how the structure of a river has been altered, and how it might change in the future to be considered in designing or planning [1].

\section{PROPOSED OUTLINE}

From the previous study, the research concludes the main features that have to be regarded in planning landscape around rivers to restore the rivers, and fulfill both the needs of rivers, and cities. These features can be summarized in: accessibility to the river, minimizing hardscapes, maximizing the usage of natural landscape, providing aesthetical values, and regarding the ecological needs (table 1).

Table 1: Main features to be regarded in planning landscape around rivers

\begin{tabular}{|c|c|c|c|c|}
\hline Accessible & $\begin{array}{c}\text { Minimize } \\
\text { hardscape }\end{array}$ & $\begin{array}{c}\text { Natural } \\
\text { landscape }\end{array}$ & $\begin{array}{c}\text { Aesthetic } \\
\text { values }\end{array}$ & Ecology \\
\hline
\end{tabular}

\section{SELECTED RESTORED RIVERS}

Aiming at testing the proposed outline for the most important features that have to be regarded in planning landscape around rivers, the research selected four rivers in different countries to apply the proposed outline on them.

\subsection{The Lower Don River, Toronto}

The river (fig.1), used to suffer from negligence, and urban decay. Finding a solution for the river required to combine the City's needs for floodwater, and different uses in the area, residential, commercial, and industrial, paired with the community's desire to restore ecological function, and recreation along the river. The local development authority, sponsored an international design competition, with teams representing landscape architects, urban planners, river hydrologists, and geomorphologists. The team have designed a plan to develop the city by a revitalized riverine ecology, flood management, management of sediment and debris, and recreational opportunities [15]. The development fulfill many of the features in the proposed outline, it provides passages around the river to achieve accessibility, decreases hard elements, uses green paths to maximize green areas,
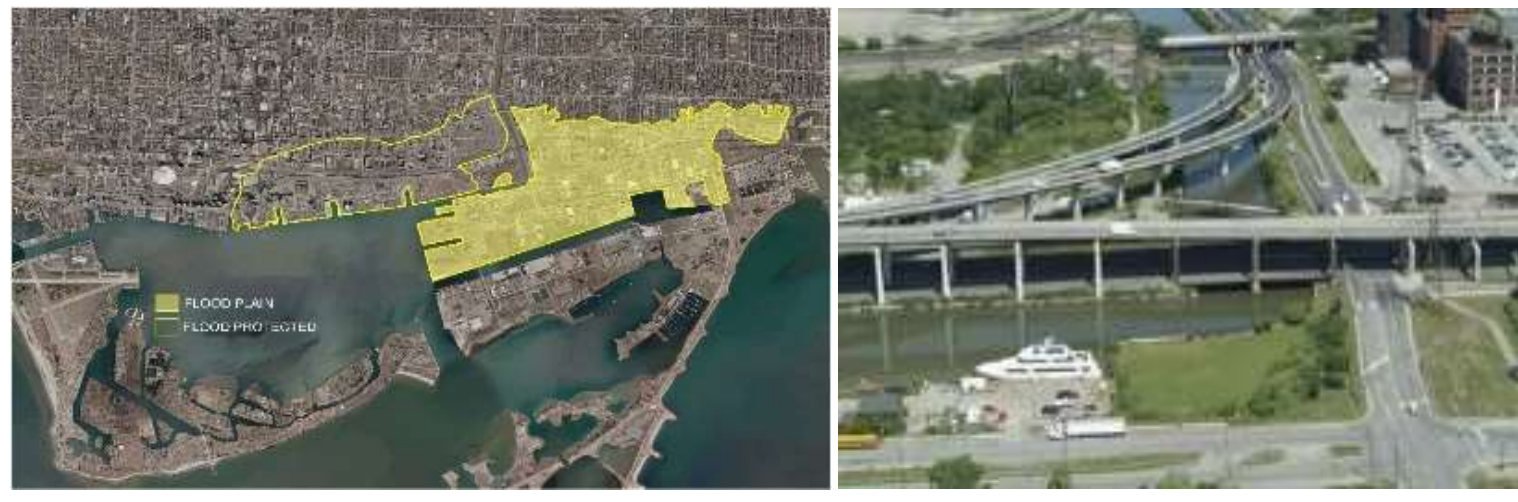
and establishes recreational areas (table 2)

Figure 1: Lower Don River, Toronto [16]

Table 2: Main features in planning landscape around Lower Don River

\begin{tabular}{|c|l|c|c|c|}
\hline \multicolumn{5}{|c|}{ Landscape around Lower Don River } \\
\hline Accessible & $\begin{array}{c}\text { Minimize } \\
\text { hardscape }\end{array}$ & $\begin{array}{c}\text { Natural } \\
\text { landscape }\end{array}$ & $\begin{array}{c}\text { Aesthetic } \\
\text { values }\end{array}$ & Ecology \\
\hline $\begin{array}{c}\text { Passages for } \\
\text { people }\end{array}$ & $\begin{array}{l}\text { Pedestrian } \\
\text { paths }\end{array}$ & Using greens & $\begin{array}{l}\text { Recreational } \\
\text { opportunities }\end{array}$ & Management \\
\hline
\end{tabular}

\subsection{Khan River, Tehran}

Rivers in Tehran are considered as main structural elements in the urban ecological system. Parts of Kan River (fig.2) valleys have been rehabilitated by the municipality of Tehran. Natural characteristics of river like meanders, backwaters, wetlands, and gradually sloped banks have important ecological functions. Imposing excessive hardscapes on natural, and morphological forms of the site has eclipsed the ecological role of river valley in urban fabric. Interfering in natural form of land, and designing recreational park with maximum use of hardscapes without paying attention to ecological properties of site, prove that the rehabilitation has been replaced by recreation. In fact the ecological potentials of rehabilitating the natural elements of Tehran's landscape ecology has been ignored completely. Another problem is the lack of awareness to native plantation. The poor and incompatible vegetation can neither support nor protect biodiversity and wildlife habitats across the river valley. Unfortunately, most of the potential for creating rich green spaces has been missed due to paving for cycling, camping or parking lots [7]. The way of dealing with the river succeeded in regarding some features of planning landscape and failed in others. It succeeded in providing accessibility and recreational areas, but failed in regarding ecology, green areas, and minimizing hard areas (table 3).

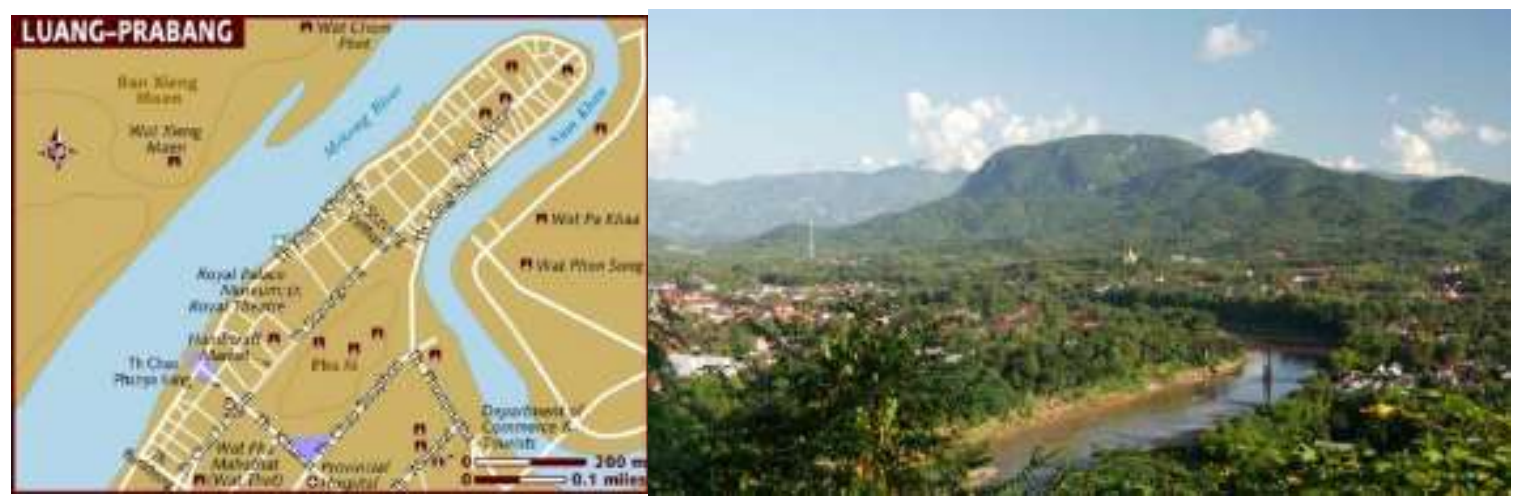


Figure 2: Khan River, Tehran [16]

Table 3: Main features in planning landscape around Kan River

\begin{tabular}{|l|l|l|l|l|}
\hline \multicolumn{5}{|c|}{ Landscape around Kan River } \\
\hline \multicolumn{1}{|c|}{ Accessible } & \multicolumn{1}{|c|}{$\begin{array}{c}\text { Minimize } \\
\text { hardscape }\end{array}$} & $\begin{array}{c}\text { Natural } \\
\text { landscape }\end{array}$ & $\begin{array}{c}\text { Aesthetic } \\
\text { values }\end{array}$ & Ecology \\
\hline $\begin{array}{l}\text { Paving for } \\
\text { cycling, } \\
\text { camping, and } \\
\text { parking lots }\end{array}$ & $\begin{array}{l}\text { Using } \\
\text { excessive } \\
\text { hardscape }\end{array}$ & $\begin{array}{l}\text { Poor } \\
\text { plantation }\end{array}$ & $\begin{array}{l}\text { Recreational } \\
\text { park }\end{array}$ & $\begin{array}{l}\text { Ignorance for } \\
\text { the ecology }\end{array}$ \\
\hline
\end{tabular}

\subsection{Elbe River, Hamburg}

The city of Hamburg is located on the river Elbe (fig. 3), most of the northwestern bank has become disused for port functions until 1997, and has thus been regenerated for urban use. This regeneration area offers an amazing opportunity on the banks of the river Elbe. This project area takes place between the historic Speicherstadt warehouse district, and the River Elbe, there will be a new city with mixed uses. In the Project area, elevated footpaths, waterproof parking basements, and the accessible waterfronts have provided a successful combination of safety, and spatial quality of urban spaces. As a solution for the accessibility of water at all times in the very high quays, a descending 'landscape' of surfaces was used. Besides, Hafencity Project points out a highly attractive public transport system. According to this, pedestrian ways are more dominant than vehicle ways. Also 70 $\%$ of pedestrian ways are away from the streets, and bicycle paths take place in the area. This project considered sustainability principles. There was a notable economic use of energy. In this context, eco-friendly building materials were used [14]. Dealing with Elbe River was successful regarding all the main features of planning landscape around rivers that is concluded in the present paper because this policy towards Elbe River provides accessibility, minimizes hard areas, maximizes
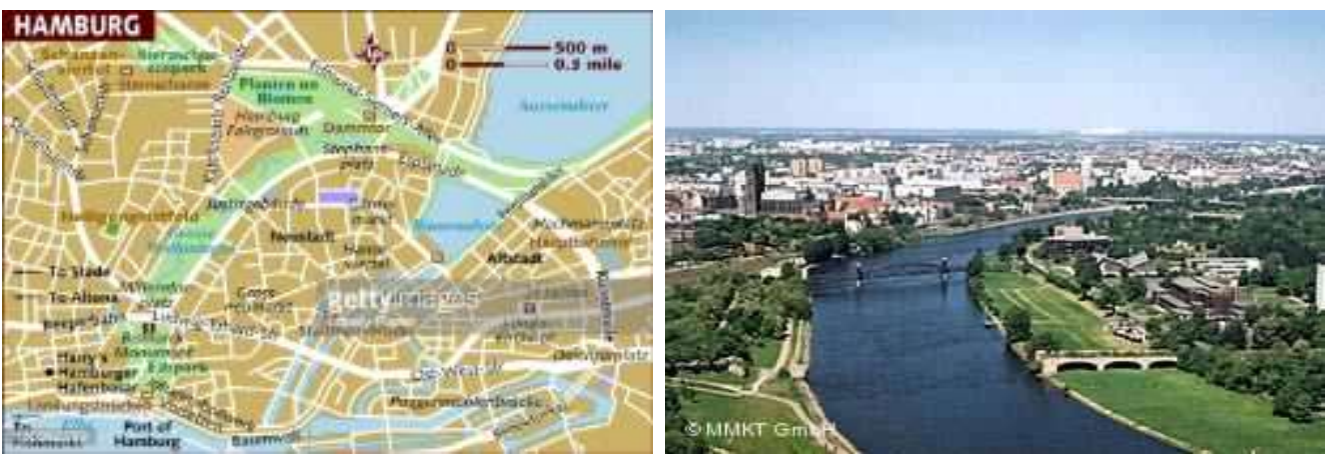

gree

$\mathrm{n}$

areas

, and

prov

ides

susta

inabi 
lity for ecology (table 4).

Figure 3: Elbe River, Hamburg [16]

Table 4: Main features in planning landscape around Elbe River

\begin{tabular}{|l|l|l|l|l|}
\hline \multicolumn{5}{|c|}{ Landscape around Elbe River } \\
\hline \multicolumn{1}{|c|}{ Accessible } & $\begin{array}{c}\text { Minimize } \\
\text { hardscape }\end{array}$ & $\begin{array}{c}\text { Natural } \\
\text { landscape }\end{array}$ & $\begin{array}{c}\text { Aesthetic } \\
\text { values }\end{array}$ & Ecology \\
\hline $\begin{array}{l}\text { Footpaths, } \\
\text { parking } \\
\text { basements, } \\
\text { waterfronts }\end{array}$ & $\begin{array}{l}\text { Vehicle, } \\
\text { pedestrian } \\
\text { ways }\end{array}$ & Using greens & $\begin{array}{l}\text { Attractive for } \\
\text { people }\end{array}$ & $\begin{array}{l}\text { Sustainability } \\
\text { for ecology }\end{array}$ \\
\hline
\end{tabular}

\subsection{Nile River, Cairo}

The Nile River is the longest river in the world, it extends for $6,670 \mathrm{~km}$ long, around which many countries exist, 22\% of the river passes in Egypt (about 160

4)
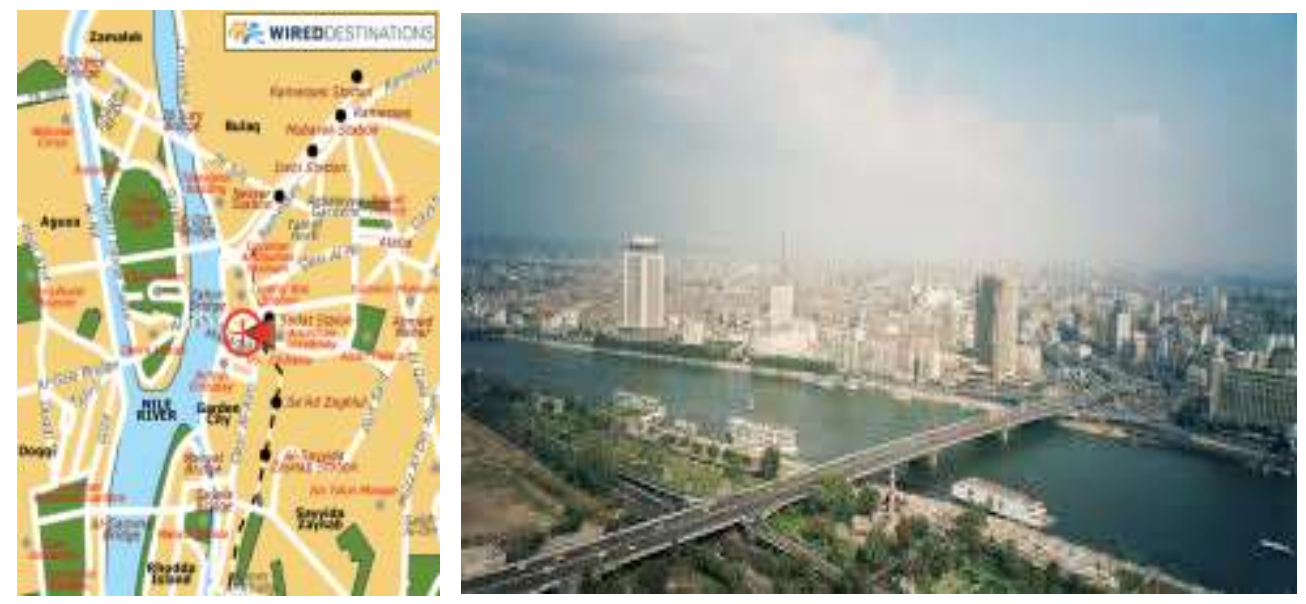

(fig.

around which people live as it means life for them [17]. 
Figure 4: Nile River, Cairo [16]

The River was called by ancient Egyptians Ar or Aur, which means the black river, this name is due to the color left by the sediment on its banks after the annual flood. Its name Nile was derived from the name neilos that was named by Greeks later on, meaning the river valley. Fertile lands extend around the river for $12 \mathrm{~km}$ wide on its either sides. Its banks attract people to establish their settlements, but their existence affect the river negatively, the most impacts are pollution, and urbanization. At the past, the River got rid of pollution naturally by the annual flood to the Mediterranean Sea. After building the High Dam, the river suffered from pollution that caused by industrial wastes, untreated sewages, rubbish, fisheries, and agricultural chemicals. This pollution leads to increase the salinity of water which in turn affects the fertility of the land [17].

Urbanization affects the River by different means, the most effects are the lack of public access to the Nile waterfront, and traffic. A partnership between the Cairo University, the American University in Cairo, and the University of California, Berkeley, established a report to develop the banks of the River to permit the public connectivity with the river in Cairo. This development is important to reconnect people to the river, develop the quality of life, strengthen the relationship between people and the river that lead to preserve it. But the report concluded some challenges that face the development such as the improper land uses around the river, and the existence of many private projects such as restaurants, clubs, and floating homes. On the other hand, there are some opportunities to develop the waterfront of the river such as: excellent views, the existence of historic landmarks and tourist attractions, the ecological restoration in many places, the roads around the river that provide accessibility, wide sidewalks that can be redesigned for public access, and the presence of vacant lots around the river that can be used as open spaces for public [18]. Roadways are constructed some 10 to $15 \mathrm{~m}$ from the river itself leaving an exposed strip of land between the road, and the river which is generally left with neither landscape nor vegetation [17]. The report uses the 
opportunities to permit the public accessibility to the waterfront such as redesigning the sidewalks and roadways around the river to permit the passage of pedestrians, and bicycles tracks with maximizing green areas [18].

Recently, the government built some projects that permit public access to the waterfront such as the area between Kasr El Nile Bridge, and 6 October Bridge which is used as a pleasant harbor for small boats in El-Gezira. In spite of being well designed as paths, it uses hard elements with few greens. Some passages around the River were designed to provide accessibility for pedestrians, but they lack either greens or ecological functions [18] (fig.5). The southern portion of this area is a $200 \mathrm{~m}$ long park called the Al-Riyadi Garden. The garden is a successful model for allowing the public to access the riverfront [17]. Moreover, some paths were established on the banks of the river to provide good scenes for the banks that has strengthened the embankment, designed stepped terraces, parks, and public spaces by the river [19].

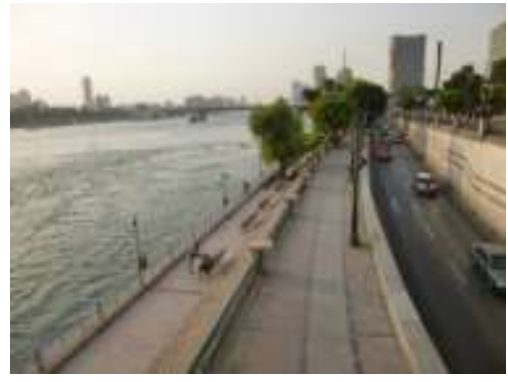

Paths using hard elements

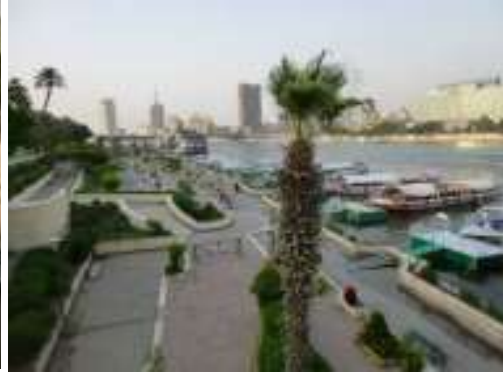

Pleasant harbor for boats

Figure 5: Banks of the Nile River [18]

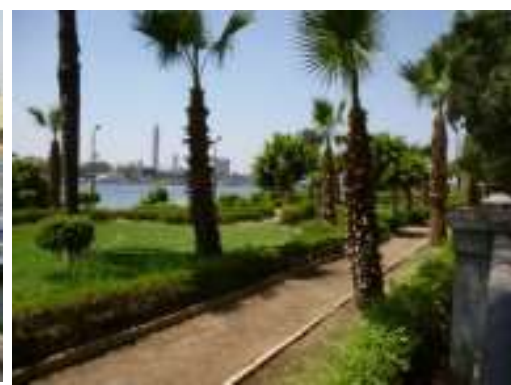

Beautiful greens

From the previous discussion, planning landscape around the river succeeded in regarding some features of landscape that are concluded in the paper and failed in many, it succeeded in providing some aesthetic values, some accessibility, but failed in minimizing hard areas and maximizing green ones (table 5). The Nile River has many opportunities for development such as the sidewalks, fertile lands, and excellent views that permit the public accessibility to the waterfront to emphasize the relationship between people and the river.

Table 5: Main features in planning landscape around Nile River

\begin{tabular}{|l|l|l|l|l|}
\hline \multicolumn{5}{|c|}{ Landscape around Nile River } \\
\hline Accessible & $\begin{array}{c}\text { Minimize } \\
\text { hardscape }\end{array}$ & $\begin{array}{c}\text { Natural } \\
\text { landscape }\end{array}$ & Aesthetic values & Ecology \\
\hline $\begin{array}{l}\text { Few footpaths } \\
\text { accessible } \\
\text { waterfronts }\end{array}$ & $\begin{array}{l}\text { High dense } \\
\text { of roads and } \\
\text { hard }\end{array}$ & $\begin{array}{l}\text { Lack of } \\
\text { greens }\end{array}$ & $\begin{array}{l}\text { Beautiful scenes } \\
\text { and few gardens }\end{array}$ & $\begin{array}{l}\text { Ignorance of } \\
\text { ecological } \\
\text { needs }\end{array}$ \\
\hline
\end{tabular}




\begin{tabular}{|l|l|l|l|l|}
\hline & elements & & & \\
\hline
\end{tabular}

\section{DISCUSSION}

As a result of the study, it is concluded that each example has its own situation in dealing with rivers, but all the examples share in the development of rivers through landscape design, as shown in table 6.

Table 6: Comparison between landscapes around the selected rivers

\begin{tabular}{|l|c|c|c|c|}
\hline Planning & Kivers & $\begin{array}{c}\text { Lower } \\
\text { Don }\end{array}$ & Elbe & Nile \\
\hline Accessible & $\checkmark$ & $>$ & $\checkmark$ & $>$ \\
\hline Minimize hardscape & $\checkmark$ & X & $>$ & X \\
\hline Natural landscape & $\checkmark$ & X & $\checkmark$ & $>$ \\
\hline Aesthetic values & $\checkmark$ & $\checkmark$ & $\checkmark$ & $\checkmark$ \\
\hline Ecology & $\checkmark$ & X & $\checkmark$ & X \\
\hline
\end{tabular}

\begin{tabular}{|c|l|l|l|c|l|}
\hline$\checkmark$ & Regarded & $>$ & Half regarded & $X$ & Not regarded \\
\hline
\end{tabular}

In planning landscape around Lower Don River, the planners regarded all the main features of landscape to develop, and restore the river as the government held a competition between experts to restore the river. In dealing with Kan River the main negative impacts are in using many roads, and pavements that maximize hardscapes which have negative impacts on the river, and used poor plantation that did not fulfill the needs of wildlife. In Elbe River, most of the main features of landscape were regarded except in using many roads, and passages to provide the accessibility to the river. Finally, in the Nile River, there are many features that were not regarded such as minimizing hardscapes, and maximizing natural landscape, as the roads are many around the river with poor plantation, even in the areas that use suitable greens, they are used as decoration more than the ecological functions.

\section{CONCLUSION}

Throughout this paper, a literature review on rivers and landscape was reviewed. The major findings are the importance of rivers, and landscape in cities, the strong relationship between landscape and rivers that are shaped by their landscapes as much as landscapes are shaped by rivers. Moreover, both rivers and landscape have positive, and negative impacts on each other. Landscape emphasizes the 
biodiversity and natural needs of rivers, but has adverse effect on rivers by using hardscapes, and rivers are considered one of the features of landscape as they provide aesthetical values to landscape, but have to be considered as main constraints for planning and designing landscape.

Then the paper proposed an outline to restore rivers through landscape by finding out the main roles of different partners: public, government, and planners. Moreover, the paper summarized the main features that have to be regarded in planning landscape around rivers which are accessibility, minimizing hardscapes, using natural landscape, providing aesthetical values, and providing ecological values. Based on these outcomes, the paper discussed four selected rivers that suffer from urbanization and how each case tried to solve the problems that faced its river through planning landscape. Finally the paper held a comparison between these examples through their deal with the main features of planning landscape, and concluded the importance of these features in developing, and restoring rivers.

\section{REFERENCES}

[1] Cengiz B. Urban river landscapes (Chapter 21). Advances in Landscape Architecture, ed. Ozyavuz M., InTech: Turkey, pp. 551-585, 2013.

[2] Kivanc M. Quality assessment methods in landscape architecture studies (Chapter 11). Advances in Landscape Architecture, ed. Ozyavuz M., InTech: Turkey pp. 280-290, 2013.

[3] Batista J., Graca M., Loupa I., Bernardo f., Methodology of aesthetic evaluation of rivers in urban context, Urban River Rehabilitation Conference, eds. Tourbier J. and Schanze J., Dresden, pp. 1-9, 2005.

[4] Zhao Y., Yang Z., XU F. Theoretical Framework of the Urban River Restoration Planning, Environmental Informatics Archives 5 (P002), pp.241247, 2007.

[5] Living Rivers in Urban Areas, Living Rivers foundation, www.living rivers.org

[6] Lifang Q. Yichuan Z. and Wei C. Evaluation of Urban River Landscape Design Rationality based on AHP. Water Science and Engineering 1(4), pp.75-81, 2008.

[7] Samiei K. Tehran, the City of River Valleys Needs a Landscape Ecological Approach to the Design and Planning of its Waterways, The Nature of Cities, www.thenatureofcities.com

[8] See E. The Threats of Urbanisation: Restoring Urban Rivers. APS 402 Dissertation, Candidate no.: 040133177, pp.1-9

[9] Lu M. and Chuanyue W. An explorative study on ecological designs of the landscape of river channels. International Conference on Remote Sensing, eds. Gahegan M. and Xiong N., Atlantis press: China, pp.83-86, 2013. 
[10] Lei Z. and Guaanghe W., Urban River Plays Key Role in City Landscape Planning-Culture Legacy and Ecological Development, www.seifbluemountain.com

[11] Rivers in our Towns and Cities, ECRR, http://www.ecrr.org/RiverRestoration/UrbanRiverRestoration/tabid/3177/De fault.aspx

[12] Communities along Rivers: Importance of Community Networking to Preserve Local Rivers, http://www.gdrc.org/oceans/river-mgmt.html

[13] Boon P.J., Davies B.R. and Petto G.E., Global Perspectives on River Conversation: Science, policy and practice, John Wiley \&sons Ltd., NewYork,2000.

[14] Pekin U. Urban waterfront regenerations (Chapter 7). Advances in Landscape Architecture, ed. Ozyavuz M., InTech: Turkey, pp. 169-206, 2013.

[15] Restoring Natural Beauty to Urban River, www.limno.com

[16] www.google.com.eg/, January 2016.

[17] Evans, A. River of Life, River Nile, http://riversoftheworld.org, 2007

[18] Kondolf G.M., (etal), Connecting Cairo to the Nile: Renewing life and heritage on the river. 2011. IURD Working Paper No. WP-2011-06. Department of Landscape Architecture \& Environmental Planning, University of California, Berkeley. http://www.laep.ced.berkeley.edu/research/cairo

[19] Eguavoen I., Waterfronts and green spaces in central Cairo-What's the way forward?, https://BLOG.ZEF.DE/?P=1808, August 30,2017 